\title{
Beyond the Fracking Ban in France
}

\author{
René Weile \\ Technical University of Applied Sciences, Wildau, Germany
}

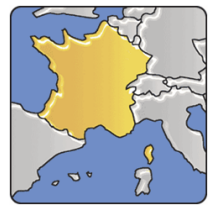

Abstract. France holds the second-largest shale gas reserves in Europe but became the first country to enact a ban on hydraulic fracturing in July 2011. A conservative government issued 64 research and exploration permits in early 2010, but half a year later a strong antifracking movement emerged which pushed for a ban. The government caved in to enormous political pressure, revoking three permits and limiting the rest. Once the Socialists won the presidency and legislative majorities, they reaffirmed a strict stand against fracking. The article shows how the ban developed and puts the government's position into the context of economic and industrial challenges. The author argues that essentially, France is waiting for discovery of environmentally friendly extraction methods. The law which created the ban still leaves some options. Also, there has been growing pressure to open up the debate about shale gas again. The article suggests possible ways to reconfigure public debate about the resources and technology.

Keywords: Economic policy, energy, energy policy, fracking, France, hydraulic fracturing, moratorium, natural gas, regulatory politics, shale gas, unconventional gas

Author: René Weile is an M.A. candidate in the European Management program at Technical University of Applied Sciences, Wildau, Germany, from which he also holds a B.A. in European Management. He studied at Zhejiang Gongshang University, Hangzhou, and currently works for a German industry association in Shanghai.

\section{Introduction}

The 2012 Gallois Report on France's competitiveness, commissioned by President François Hollande, painted a troubling picture: the economic situation in France was still affected by the financial crisis. The country was struggling to regain its former industrial strength. Growth of GDP was stagnating, reaching only 0.2 percent in 2012 . Unemployment stood at 10.8 percent, alarmingly the highest rate ever recorded. More than three million people were searching for new employment (Shale Gas Europe, 2012b). Hollande's Socialist Party-led coalition government has not been able to reduce these negative economic indicators significantly; its popularity is declining because election campaign promises could not be kept. In addition, austerity measures amplify the negative effect on the economy.
While struggling with these economic policy challenges, the French government is dedicated to reform energy policy and rearrange the country's energy mix. Currently, 58 nuclear reactors supply about 75 percent of energy demand, giving France relative high energy independence. This number is set to be reduced to 50 percent by 2025 (euractiv.com, 2012). Questions remain how this and a further transition to renewable energy sources like wind power, hydroelectric, tidal power or solar energy can be managed. Critics say France has not accomplished much in recent years. Yet the current French government is fully dedicated to the EU's climate policy goals, and as one of Europe's industry and consumption leaders, it has a leading role to play. By 2020, Europe's carbon dioxide emission ought to be reduced by 20 percent, based on the 1990 reference year. By 2030, the amount is supposed to be reduced by 40 percent and even 60 percent by 2040. In 2050, the EU member states plan to have their carbon dioxide emission reduced by $80-90$ percent (euractiv.com, 2012).

One proposition is to turn to natural gas as a transition fuel, and hopeful voices have pointed to a wealth of gas sealed in the country's ground: The U.S. Energy Information Administration estimates that France, after Poland, has the second-largest reserves of shale gas in Europe. Deposits could amount to five trillion cubic metres, of which 20-30 percent may be technically recoverable (EIA, 2013). How much gas there really is, however, can only be measured if companies were allowed to drill test wells, using the controversial hydraulic fracturing method. But since 2011, when the Nicolas Sarkozy government prohibited fracking in France, the procedure has been unavailable for exact estimates of deposits.

Among the 22 policy measures the Gallois Report recommended to the government was one to develop technology research on shale gas exploration, suggesting that unconventional gas could have profound effects on the French economy. The Report pointed to effects in the United States: As energy price decrease, the country experiences job growth and a process of reindustrialization (Shale Gas Europe, 2012b).

Reindustrialization was also something Hollande had addressed during his election campaign. Clearly, domestic energy cost is an important factor for energy-intensive French industries if they are to stay competitive and not be lured to relocate to countries like the U.S. This would threaten France with further job loss and less state income. Another aspect is reliance on imports. France has only very small conventional gas fields and has become the sixthlargest gas importer in the world, and is importing 98 percent of its gas supply, mostly from Norway (31 percent in 2010), the Netherlands (15 percent), Russia (14), and Algeria (13), with 71 percent coming in via pipeline and 29 as LNG (Energy Delta Institute, 2012). Having a greater domestic gas supply could give France an 
advantage in commercial diplomacy (Harsem \& Claes, 2013, p. 791). "If we could have a low cost national gas," renowned French energy economist Jean-Marie Chevalier has stated, "it would do wonders for the French economy and for our options for negotiations with the Russians or the Algerians" (de Saint Jacob, 2011).

\section{Fracking Fury and State Response}

With remarkable speed, France moved from a spontaneous emergence of an anti-fracking movement in late 2010 to a halfyear moratorium on fracking and then parliament passing a law for an outright ban in 2011.

In early 2010 , some twenty domestic and foreign energy firms applied for shale gas research and exploration permits by ministerial decree. The government, represented by environment minister Jean-Louis Booloo, granted permits to companies such as Total E\&P France, Schuepbach Energy (in a joint venture with GDF Suez), Mouvoil, Toreador Resources, Vermilion Energy, Bridgeoil, Hess Energy or European Gas Limited. This was not much publicized, and the parliament did not debate the decisions. Inside the government, no one really questioned the drilling permissions. There was some regulation in place covering hydraulic fracturing, and under that framework had been used dozens of times in France without any negative reports (Martor, 2012).

Although companies like Total did issue timely press releases about winning permits, facts became only widely known half a year later as a critical discussion developed in late 2010. That coincided with the release of the U.S. documentary, Gasland. Environmental groups initiated a series of events informing citizens in affected areas, partly in the Paris Basin but mostly in the French South, about shale gas, the fracking method, and the U.S. experience as presented by Gasland. The film was routinely used in town meetings. Other aspects factored in. For example, an unusual spring drought sensitised farmers about water management, and a region set for unconventional gas exploration, the Causses-Cévennes, was marked as an Unesco world heritage site, stirring controversy about possible damage by industrial development (de Saint Jacob, 2011). A number of arguments against hydraulic fracturing were brought up: First, people and communities near drilling sites could suffer from stress, noise and traffic by site construction. The second negative aspect was seen in using tremendous amounts of water, possible impact of chemicals on ground water, and waste water disposal. The biggest concern was contamination of drinking water. Fear and controversy was intense, and politicians became very aware of this.

The French countryside saw rallies, demonstrations and petition drives in otherwise very quiet villages and communes. Local groups of citizen activists ("collectifs"), mayors, councils, and heads of départements soon drafted protest resolutions, protest websites were created, and mainstream media echoed the new movement's campaigns. José Bové, a Green Party (Europe Écologie-Les Verts, EELV) member of the European parliament and well-known environmental activist, was among the prominent campaigners from established party opposition - particularly the Greens and the Socialists, but also the radical right's Front National - to the government led by Nicolas Sarkozy's Union pour un Mouvement Populaire (UMP).

Clearly the opposition hoped to increase its political capital from building pressure before upcoming elections - a September 2011 election for the Senate, which is primarily chosen by municipal officials, and the presidential and parliamentary elections in 2012.

As a result of their efforts, environmentalists and residents of the concerned regions forwarded a petition of more than 100,000 signatures to the French parliament (Patel, 2011).

\section{From moratorium to prohibition}

In February 2011, Prime Minister François Fillon's government announced a drilling moratorium which was in April extended to June. A scientific commission was asked to study potential ecological impact. The new UMP environment minister, Nathalie Kosciusko-Morizet, called her predecessor Booloo's permits an "error." The permits should have never been issued, as the fracking technology is uncontrollable, and the U.S. experience had shown substantial damage to the environment. Independent from the technology, Kosciusko-Morizet said, opening up a new global age of fossil fuels would be the wrong policy (AFP, 2011). Meanwhile, the movement's initial moratorium demands were replaced by more radical calls for a total ban on fracking. Economists and technical experts put up counter arguments in an energized debate, but their efforts were futile as anti-fracking pressure mounted.

In March 2011, bills against fracking were introduced in the parliament, which intensely debated. One bill was proposed by conservative UMP member Christian Jacob, who won government support. His bill would become informally known as "loi Jacob," the Jacob Law. In July 2011, the National Assembly and Senate passed Law 2011-835. It forbids "exploration and exploitation of liquid or gaseous hydrocarbons through hydraulic fracturing" and enables government to discontinue "the research permits which include projects using hydraulic fracturing" (Martor, 2012).

So France became the first country in Europe - indeed, in the world - with a concrete legal, indefinite ban on fracking. Notably, the ban was passed by a conservative party majority under a conservative president who otherwise was known for pro-business and pro-industry views, not particularly for environmental concerns. The law can be interpreted partly as a tactical response to a perceived political threat in rural France.

From the law it followed that three permits for operating companies were cancelled immediately. These directly hit Total and Schuepbach Energy. The other 61 permits, including projects for conventional gas and oil, were allowed to stand when companies verified that they were not making use of hydraulic fracturing. Since the government did not forbid mining of unconventional gas in general but only the method of hydraulic fracturing, there is still an open door for other methods (Götze, 2011).

Thus, adversaries were not fully satisfied with this law because it still provides scope for discussion and interpretation. Radical opponents argue for a law that forbids any sort of fracking. Moreover, they do not trust the companies which could retain their permits. Naturally, the energy companies were not satisfied with this solution either. Companies like Total, GDF Suez and foreign firms have continued to lobby and publicly argue to revive the debate about "hydro fracking." But so far, the French government has rigidly kept to its position and refuses all incoming requests.

\section{The President's strong stand and a fractured cabinet}

Upon his 2012 election, President Hollande made a personal stand that during his presidency, fracking would stay banned. That implies that even an open discussion about the subject is non desired. The government does not show any interest in discussing new solutions or any changes to existing laws. Authorities are very precautious, because they know how sensitive the French people are about the topic and because they know that the gas will remain in the ground. It can still be extracted at a later point in time, as safer extraction methods may become available.

In July 2012, Environment and Energy Minister Delphine Batho (Socialists) reaffirmed: "The government clearly and distinctly maintains the ban on exploiting shale gas because nowhere in the world has it been proven that this exploitation can be done without significant environmental damage and important health risks" (Phys.org, 2012). 
In September 2012, President Hollande opined that fracking involved "heavy risk to health and the environment;" he announced that his government was to reject seven pending applications for drilling permits in the South from companies looking for shale gas. No permits would be given during his presidency (Shale Gas Europe, 2012c).

The Socialist Party includes some politicians more friendly to shale gas development. As an often provocative voice in the cabinet, Industry Minister Arnaud Montebourg is openly in favour. "Occasional harm from fracking is a reality," he admitted but said if natural gas were to reduce nuclear energy, "it would be better to produce it here than import it. This question has to be put on the table" (Patel, 2012).

He has also floated the idea that, in line with classic French industrial policy, a state-backed or state-owned national company might be created to keep shale gas exploration under exclusive public control, and proceeds could finance the transition towards green energy (Gentili, 2013). Montebourg believes France should exploit its shale resources in an "environmentally friendly" way. "A new generation of clean technologies can allow extraction without destruction," Montebourg has stated, emphasizing "we could come up with the technology in a very short time to be able to exploit the gas ecologically" (McPartland, 2013).

But on this question, Montebourg is isolated in Hollande's cabinet. One reason why that is so, it has been suggested, is the Socialists' reliance on Greens/EELV support. "Everyone is aware that there is a political issue that involves the relationship between parties forming the presidential majority," said secretary-general of the CGT labour union, Bernard Thibault. The president had to satisfy their requests in order to count on them in other political areas (Grealy, 2012).

While the Greens have only had limited electoral success, green issues today have a far wider appeal to the general public than only a decade ago. Even conservatives have conformed with this, supporting the 2005 amendment to the constitution of "Charte de l'environnement" and for a path toward sustainability and a strong precautionary principle in policy-making.

Another reason why shale gas is lacking popularity among the French is probably because there are differences in mineral rights ownership. Landowners in the U.S. can claim property rights not only on what is on their ground but also what is beneath it; this includes all raw materials and precious resources (Wang \& Krupnick, 2013). Such economic incentives can reduce local residents' resistance as they lease the rights for substantial income. That is not the case in France and hence, they are solely expecting disadvantages and inconveniences.

\section{The Legal Framework}

The process of hydraulic fracturing falls under the Mining Code in France. The code includes protection of water and environment. Both are affected by the procedure. According to Mitchell and John (2011), there is a certain procedure for handling requests for fracking. If a company wants to drill in a certain area, it has to apply for an exclusive research permit from the minister responsible for mining. Application documents have to include who might be affected by the measures, for example residents near the drilling site. There is only a $200 \mathrm{~m}$ distance required to other persons' property. If the permit is granted, the applicant receives ownership on everything he finds beneath the ground. The minister conveys the responsible prefect of the area. The prefect has to seek consultation with local environment, development and housing agencies in order to hear different sides. Having built his opinion according to the given information and advice, the prefect gives feedback to the minister (Mitchell \& John, 2011).

\section{Scope for research and alternatives}

Three additions to the law are noteworthy. A first required that a special commission be formed to provide well-founded opinion on research-based experiments with hydraulic fracturing. This commission includes industry and science, local authorities and state representatives. It was expressly set up for the purpose of orientation, monitoring and evaluation. This special commission has the competence to authorize an operator to exceptionally use hydraulic fracturing for scientific purposes.

A second clause is about the necessity of reports from operators. Those who still retain permits are supposed to send reports periodically in order to prove that they are not using hydraulic fracturing. A third addition requires annual commission reports, and in turn, government reports to the parliament, about developments in other countries. If there are any breakthroughs or innovations that could be interesting for France, the government can suggest changes in the legal framework. Moreover, the results of publiclycontrolled hydraulic fracturing research shall be reported (Mitchell \& John, 2011).

The law gives some insight to the government position towards fracking. Its definition is rather vague, and it has been suggested that alternative methods, close to fracking but called stimulation instead, might be admissable. There is still scope for experiments. If there is any solution that does not involve hazardous chemicals, the law could be bypassed. The law also shows that the fundamental decision is postponed to a later point in time, when the procedure may be sufficiently safe in the government's assessment. The law's purpose is to gather more information.

The government is observing how European neighbours deal with the issue. Since the reports required by the commission are annual, one can conclude that a possible change of course will take years because reporting periods are rather long. There is also the commission, working as a quiet forum for open discussion about the technology, and it is even able to grant permits on an exception basis

The ban is therefore not absolute; it is based on the premise that research and better technology may lead to a legalisation of fracking procedures. Finally, the law did not revoke all 64 permits, allowing companies to keep their investment commitment and pursue exploration, albeit under some restraint, until the situation has improved for them (Mitchell \& John, 2011).

The government likely had in mind that companies might sue in court for civil damages if all licenses had been revoked (de Saint Jacob, 2011). France has not given up completely on the idea of exploiting unconventional gas, and the law is not at all prohibiting searching for it. It only restricts utilisation of a specific technique.

\section{Business: Trying to Reopen Debate}

The 2011 act affected several energy companies. Two companies stood out because their permits were revoked: Schuepbach Energy, which had two research permits for about 9,000 square kilometres in the South of France and in the Paris Basin, and French company Total, which for decades has engaged in conventional natural gas in the Southwest of France (Lacq and Meillon fields).

Total had initially received permission to explore about 4,300 square kilometres in Southern France (South of Valence to the Montpellier region). The company tried to regain permission in Montelimar, pledging to only use conventional technologies. The company is very keen to explore new shale gas opportunities not only in their home market but also in worldwide (North and South America, and China) and in Europe, i.e. the United Kingdom, in Denmark and Poland (Oil and Gas Financial Journal, 2013). 
The company illustrates in a presentation for stakeholders a number of key arguments that speak for unconventional gas. For example, Total argues that as conventional gas production is declining, unconventional gas becomes progressively more important to the energy mix of industrialized nations. The firm also makes the case that it is of great importance for France to diversify energy supply to avoid too high dependency which could bare risks and be disadvantageous. Security of gas supply is of high significance for European countries, the firm insists (Total, 2012).

Total shows great interest in reopening the debate about shale gas in France. In the firm's perspective, France is missing a big opportunity. The company has proposed to the government that it could conduct publicly-controlled research in order to provide data for independent researchers. In addition, Total suggests its own research and development may help making fracking more environmentally friendly. The firm operates in the United States and there collaborates with local energy companies, such as Chesapeake Energy, in order to share knowledge and experience. Total, as other oil and gas companies, lobbies the ministry of economy and environment (Rose, 2012). It also has not been shy to take its arguments public and launch a media effort to turn the debate around. For example, Total invited French journalists to visit its partner Chesapeake Energy's fields in America (upi.com, 2012).

\section{"They wanted my scalp"}

But the energy sector alone is unlikely to have enough political capital to reopen debate and sway the country's leadership and public opinion; even though industry champions like Total and GDF Suez are affected and have the French Union of Petroleum Industries (UFIP) on their side. A broader alliance would seem necessary to build support, and there is one emerging.

Following President Hollande's outright no to shale gas under his presidency, in a September 2012 open letter to Hollande published in business magazine $L^{\prime}$ Usine Nouvelle, 22 leaders appealed to reconsider the debate. Among those were powerful and influential people (De Jaegher, 2012). "We, the representatives of the industrial community, of its leaders, executives, technicians and workers, wish for a reopening of the debate on France's potential in terms of shale gas," the appeal read.

The country has a "duty" to study its resource potential, and has a "unique chance" to be a leader in developing "clean" extraction methods. Once all the facts were on the table, "enlightened choices" could and should be made. "We ask the president to open a major national, public debate on shale gas, involving all relevant parties - citizens, NGOs, industrialists and researchers," the signatories wrote (Connexion, 2012).

They included Laurence Parisot, president of the French Business Confederation MEDEF, representing 750,000 companies; electronic firm Radiall's CEO Pierre Gattaz, also president of the Group of Industry Federations (GFI) and the Electronic Industries Association FIEEC; Philippe Gobel, president of the Chemical Industries Union (UIC); Laurent Chabannes of the Energy Suppliers' Union (Uniden); François Roubaud of the Employers' Confederation of Small and Medium Enterprises (CGPMF), and a range of other business association leaders and top managers from firms such as Sanofi, Solvay, or ST-Ericsson. Bernard van Craeynest of the CFE-CGC labour union joined, as did university presidents (De Jaegher, 2012).

The open letter's impressive line-up calling for a national debate proves that industry leaders, already engaging in open public criticism of Hollande's economic policies, are willing to challenge the government's dominant wait-and-see attitude even if it means very public controversy which politicians would like to shy away from.

How powerful these shale gas advocates was experienced by environment and energy minister Delphine Batho, who in June 2013 went on a television and radio duel with Laurence Parisot of
MEDEF about shale gas and hydraulic fracturing. A strong supporter of renewable energy and nuclear phase-out, Batho was also one of the most enthusiastic opponents of the shale gas industry. In the heated debate with MEDEF president Parisot, who sharply criticised the "ad infinitum" prohibition policy for preventing a debate based on reliable data and better technology, Batho argued that any effort to look for shale would reduce necessary investment in renewable energy. She would not accept Parisot's suggestion that shale gas could be useful as a transition fuel and contribute to financing renewables. The two women agreed only on one point, that France must reduce its dependence on gas imports, specifically Russian. But again, Batho would rather develop domestic biogas than allow for shale gas (Garoscio, 2012).

Shortly after, Batho was dismissed from her position as environmental minister, formally for criticising budget policy; but in a press conference, she held industry groups responsible: "The battle crystallized notably on the question of shale gas and more discreetly on the reduction of nuclear in France," Batho said; "these forces that I am talking about wanted my scalp." (Natural Gas Europe, 2013; Patel, 2013). However, her successor Philippe Martin is also considered a long-time fracking critic.

\section{The fracking ban - unconstitutional?}

Industry has also chosen to challenge the government by litigation. American company Schuepbach Energy put its case before a regional administrative court, claiming its property and freedom of enterprise rights were violated by an unconstitutional law - the "loi Jacob" fracking ban, which had had the immediate effect of state withdrawal of the firm's exploration licenses. Schuepbach said this went way beyond the precautionary principle anchored in the constitution's environment charter, was disproportionate and also discriminatory: Schuepbach argued that hydraulic fracturing was just banned for search of shale gas but not for geothermal projects (Pottinger, 2013).

Opinions differ whether stimulation used in geothermal sourcing is comparable to hydraulic fracturing. Hence, geothermal and gas extraction methods were not treated equally under the law. Apparently, drilling for geothermal sources bares slightly less risks than shale gas extraction but Schuepbach definitely had a reasonable point to argue (Bloomberg, 2013).

The case was referred as a priority issue of constitutionality (QPC) to the Constitutional Council - a legal decision-maker of last resort. In October 2013, the Council upheld the law as constitutional, and dismisses Schuepbach's arguments on all points (Conseil constitutionnel, 2013). Slim were then also chances of suing the French state for damages, claiming compensation for up to one billion euros in missed profits from 50 years' gas production (Schaub, 2013).

\section{Future Prospects}

In the near future the position of the French government will probably remain unchanged. Political tactics and election dates will continue to play a role; the next local elections in spring 2014 require parties have to position themselves. The national government has clearly a precautious approach towards shale gas, fearing negative effects on the environment - and so do the people of France.

Public opinion definitely plays a decisive role. It was a broad popular movement that initially moved the Sarkozy/Fillon government to take action against the energy companies. Hollande's Socialists have even more reason to be very cautious in handling an unpopular, controversial issue. That shows that the people have great power over their government and that the government is very 
likely to be influenced by strong movements. Unless public opinion changes, it is very unlikely that the government reverses course. So far, there are only a few options to change the minds of the citizens.

A first opportunity might lie in new technologies and procedures which could replace current fracking practices. If they were less potentially harmful to health and environment, they could change the debate. At the moment research projects are going on, new promising technologies are being tested and improved. For example, pneumatic fracturing makes use of compressed air without hazardous chemicals, and also increases efficiency.

One disadvantage of hydraulic fracturing is that it is very inefficient; only 20 percent of gas can be extracted from deposits. If that number were to increase drastically, it could make a difference. Another alternative might be gas extraction through electro shocks and pure water. But such attempts to make fracking "greener" will, according to scientists, need several years to mature (Xenius, 2013). Government-industry research cooperation could prove beneficial to amplify the process. The government should have economic incentives in finding environmentally friendly ways to extract gas.

Secondly, economic incentives for landowners and near-site communities which outweigh inconveniences might change the level of public acceptance. In essence, the public, particularly at the local level, is asking for "a better deal:" Parts of the anti-fracking movement are not in total opposition to unconventional gas or the fracking technology, but want positive perspectives on economic opportunity, taxation and compensation - and do not want local communities to bear only long-term ecological and public health costs. This also is connected to the perception that global, especially U.S., firms dominate the gas projects and would take their profits abroad (Control Risks, 2012).

The question of "what's in it for me?" is one that is debated across European countries, and so are the issues of a governmentmandated or company-offered "citizen dividend" or "community dividend." As long as public advantages stay abstract (energy supply security etc.) and only corporate profits look concrete, it is plausible that citizens and municipalities stay very sceptical and do not see themselves as positive stakeholders.

Third, energy companies have to do their job and to educate people as stakeholders. This is particularly true when, as in France, personal experience with industrial oil and gas field development is very limited or non-existent. If firms want people's approval for substantial changes in their environment, using questionable technology, they have to provide information. They have to engage with communities and major interest groups (Leifheit, 2011).

In France, the firms' applications for research and exploration permits came across as a stealth operation; the public was kept in the dark. Environmental groups framed the terms of debate when facts came out and companies began to start operations. Unsurprisingly, citizens and communities turned hostile.

Companies failed in early communication. For new projects, they should first try to inform the people via a range of media and personal channels in order to increase awareness. For those residents who are directly affected by a drilling site, it would be wise to invite them to an existing site to show the works, and the safety and environmental precautions the company takes responsibility for. If methods become less strange and more familiar, people may be able to develop trust.

Fourth, the French economy has serious structural problems and may not improve even in the long run. High unemployment and stagnant growth may induce government and public to give new technologies and innovation a chance to provide jobs and create a growth sector. The more people's dissatisfaction increases, the more probable it becomes that the French government will open up debates about alternative paths - and that may include fracking.
At one point, economic needs may outweigh concerns for the environment. Certainly research and a handful of gas projects cannot have a substantial economic impact overnight. But energy companies could recruit a decent number of new employees, build fields and infrastructure. Some domestic supply may help decrease energy prices, improve competitiveness of French firms and the country's attractiveness for investors (Shale Gas Europe, 2012a).

Fifth, government and industry research provides information which could make public decision-making more transparent for citizens, which in turn should be involved at every step. With support of an expert task force, government could establish clear criteria that have to be fulfilled for getting permission. This approach was chosen by South Africa. The country also had a moratorium on shale gas exploitation but after giving time to a task force for investigation they opened the process again and issued permits exclusively for operations which passed a strict review and fulfilled criteria. This involved public consultation with affected stakeholders (Shale Gas Europe, 2012c).

\section{Conclusion}

When the people's movement demanded action from the French government, they were given a law which seemingly offers a few niches but still works as a strict ban to hydraulic fracturing as a method. A closer look at the law and the government's positioning reveals that Paris is still interested in the subject but prefers to observe development in other European countries and wait for more environmentally friendly extraction methods. That is neither implausible nor unwise, both in terms of politics and in terms of technology risk assessment.

It is also understandable that French and foreign companies are impatient. But irreversible mistakes have been made several years ago. Companies and government failed to establish a transparent process and to appropriately educate the public. For those looking for ways to change the perception of fracking, they cannot ignore citizens and communities as major stakeholders.

France has the second-largest reserves of unconventional gas in Europe, so it is unlikely anyone can afford to ignore this economic asset in the long run. It is true that the resource will remain valuable and can be extracted later, when it would still be a welcome economic driver and helpful to reduce import dependency. At the moment France's energy situation is not critical, thus the country can remain observing. Perhaps France can benefit from research breakthroughs or developments of other countries. But that is of course not a way to demonstrate technology leadership, of which France has always been so proud.

\section{References}

AFP (2011, May 10). Gaz de schiste: Borloo a fait une"erreur" affirme Kosciusko-Morizet. Retrieved December 20, 2013, from Le Point: http://www.lepoint.fr/politique/gaz-de-schiste-borloo-a-fait-uneerreur-affirme-kosciusko-morizet-10-05-2011-1328753_20.php

Bloomberg (2012, September 16). In France, backers of fracking to fight ban. Retrieved September 09, 2013, from

http://triblive.com/usworld/world/2614885-74/shale-explorationfracking-hollande-ban-energy-france-french-gaslicenses\#axzz2ePZVf5fD

Bloomberg (2013, April 08). France fractured by fracking-like geothermal projects. Retrieved September 10, 2013, from http://www.smh.com.au/business/france-fractured-by-frackinglikegeothermal-projects-20130407-2heul.html

Connexion (2012, September 21). Bosses demand shale gas re-think. Retrieved December 20, 2013, from The Connexion: 
http://www.connexionfrance.com/Business-Parisot-Medef-UsineNouvelle-shale-gas-14099-view-article.html

Conseil constitutionnel. (2013, October 11). Decision no. 2013-346 QPC of 11 October 2013 Schuepbach Energy LLC [Prohibition of hydraulic fracking in relation to the exploration and exploitation of hydrocarbons - revocation of licences to prospect]. Retrieved December 20, 2013, from Conseil constitutionnel: http://www.conseilconstitutionnel.fr/conseil-constitutionnel/english/priority-preliminaryrulings-on-the-issue-of-constitutionality-qpc-/sample-of-decisionsqpc/2013/decision-no-2013-346-qpc-of-11-october-2013.138596.html

Control Risks. (2012). The global anti-fracking movement: What it wants, how it operates and what's next. White paper. Retrieved December 20, 2013, from Control Risks:

http://www.controlrisks.com/Oversized\%20assets/shale_gas_whitepap er.pdf

De Jaegher, T. (2012, September 19). Gaz de schiste : 22 personnalités de l'industrie appellent à relancer le débat. Retrieved December 20, 2013, from L'Usine Nouvelle:

http://www.usinenouvelle.com/article/gaz-de-schiste-22-personnalitesde-1-industrie-appellent-a-relancer-le-debat.N182212

de Saint Jacob, Y. (2011, July 21). France's 'green vote' kills shale gas and targets nuclear power as well. Retrieved September 04, 2013, from European Energy Review:

http://www.europeanenergyreview.eu/site/pagina.php?id=3154

EIA. (2013). France. Retrieved July 02, 2013, from US Energy Information Administration: http://www.eia.gov/countries/countrydata.cfm? fips $=$ FR

Energy Delta Institute. (2012). Retrieved September 03, 2013, from http://www.energydelta.org/mainmenu/energy-knowledge/countrygas-profiles/country-gas-profile-france\#t42771

euractiv.com. (2012, September 07). Hollande deals setback to nuclear shale gas industries. Retrieved September 03, 2013, from http://www.euractiv.com/energy/hollande-deals-blow-nuclear-shalnews-514819

euractiv.com. (2012, September 17). Hollande: Aus für AKW Fessenheim und Fracking. Retrieved September 03, 2013, from www.euractiv.de/druck-version/artikel/hollande-aus-fuer-akwfessenheim-und-fracking-006725

Garoscio, P. (2012, June 5). Gaz de schiste: vif débat Batho-Parisot avec Bourdin comme témoin. Retrieved December 20, 2013, from JOL Press: http://www.jolpress.com/gaz-schiste-ecologie-environnementdebat-batho-parisot-bourdin-bfm-rmc-article-819969.html

Gentili, V. (2013, July 11). Arnaud Montebourg proposes state agency to control shale gas exploitation. Retrieved December 20, 2013, from SeeNews: http://energy.seenews.com/news/arnaud-montebourgproposes-state-agency-to-control-shale-gas-exploitation-365156

Götze, S. (2011, October 13). Das Aus für Schiefergas. Retrieved September 03, 2013, from www.heise.de/tp/druck/mb/artikel/35/35638/1.html

Grealy, N. (2012). The shale gas debate in France is just starting. Retrieved September 2013, from http://www.nohotair.co.uk/gas-gurublog/shale-gas-2012/175-current-affairs/2635-the-shale-gas-debate-infrance-is-just-starting

Harsem, Ø., \& Claes, D. H. (2013, April). The interdependence of European-Russian energy relations. Energy Policy, 59(C), 784-791.

Leifheit, D. (2011, September 28). Communications challenges in the unconventional world. Retrieved September 03, 2013, from Natural Gas Europe: http://www.naturalgaseurope.com/communicationschallenges-in-the-unconventional-world

Martor, B. (2012, March 12). France: Evolutions in the legal framework for shale oil and gas. Retrieved December 20, 2013, from Shale Gas Information Platform: http://www.shale-gas-informationplatform.org/de/categories/legislation/expert-articles/martorarticle.html

McPartland, B. (2013, July 11). France engulfed in new row over shale gas. Retrieved December 20, 2013, from The Local: http://www.thelocal.fr/20130711/france-engulfed-in-new-row-overshale-gas

Mitchell, A., \& John, D. (2011, December 21). Slideshow on unconventional gas regulation in France. Retrieved September 03 , 2013, from http://www.strategicfit.co.uk/upstream/unconventionalfrance/

Natural Gas Europe. (2013, June 06). Could Batho's Dismissal Change Cards on French Shale Table? Retrieved September 09, 2013, from http://www.naturalgaseurope.com/batho-dismissal-french-shale-table
Oil and Gas Financial Journal. (2013, January 14). France's Total to develop shale play in Denmark. Retrieved September 04, 2013, from http://www.ogfj.com/articles/2013/01/france-s-total-to-develop-shaleplay-in-denmark.html

Patel, T. (2011, March 31). The French Public Says No to 'Le Fracking'. Retrieved September 04, 2013, from http://www.businessweek.com/magazine/content/11_15/b4223060759 263.htm

Patel, T. (2012, November 28). France can frack without destroying environment, Montebourg says. Retrieved December 20, 2013, from Bloomberg: http://www.businessweek.com/news/2012-11-28/francecan-frack-without-destroying-environment-montebourg-says

Patel, T. (2013, July 13). Fired French minister says shale backers sought her scalp. Retrieved December 20, 2013, from Bloomberg: http://www.bloomberg.com/news/2013-07-04/former-french-ministersays-support-for-frack-ban-behind-firing.html

Phys.org. (2012, July 12). France maintains shale gas ban: environment minister. Retrieved September 09, 2013, from http://phys.org/news/2012-07-france-shale-gas-environmentminister.html\#nRly

Pottinger, K. (2013, July 01). Shale Gas: Schuepbach challenges French Ban. Retrieved September 10, 2013, from http://www.french-newsonline.com/wordpress/?p=27523\#axzz2caGQSJj1

Rose, M. (2012, September 25). Analysis: Clock ticking on French fracking veto. Retrieved September 03, 2013, from http://www.reuters.com/article/2012/09/25/us-energy-shale-franceidUSBRE8800J720120925

Schaub, C. (2013, October 11). Le Conseil constitutionnel valide l'interdiction des gaz de schiste. Retrieved December 20, 2013, from Libération: http://www.liberation.fr/terre/2013/10/11/le-conseilconstitutionnel-se-prononce-sur-l-interdiction-des-gaz-deschiste_938555

Shale Gas Europe. (2012a, November 20). An Opportunity for Economic Growth in France is Not Absurd but Essential. Retrieved September 03, 2013, from http://www.shalegas-europe.eu/en/index.php/newsroom/blog/entry/an-opportunity-for-economic-growth-in-france-is-notabsurd-but-essential

Shale Gas Europe. (2012b, November 06). The Gallois Report: How Long Can France Reject Shale Gas? Retrieved September 03, 2013, from http://www.shalegas-europe.eu/en/index.php/newsroom/blog/entry/the-gallois-report-how-long-can-france-reject-shalegas

Shale Gas Europe. (2012c, September 22). When the (Gaz de) Schiste Hits the Fan. Retrieved September 03, 2013, from http://www.shalegas-europe.eu/en/index.php/newsroom/blog/entry/when-the-gaz-de-schiste-hits-the-fan

Total. (2012, April 25). EU security of supply. Retrieved September 04 2013, from

http://www.gasnaturally.eu/uploads/documents/gas_week_2012/April $\% 2025 \% 20$ Gas $\% 20$ Naturally $\% 20$ TOTAL $\% 20$ final $\% 202 \% 20$ security $\% 20$ of\%20supply.pdf

upi.com. (2012, August 27). French PM: Shale gas future not settled. Retrieved September 04, 2013, from

http://www.upi.com/Business_News/EnergyResources/2012/08/27/French-PM-Shale-gas-future-not-settled/UPI$90771346063400 /$

Wang, Z., \& Krupnick, A. (2013, April). A Retrospective Review of Shale Gas Development in the United States. Retrieved September 04, 2013, from http://www.rff.org/RFF/documents/RFF-DP-13-12.pdf

Xenius. (2013, Juli 12). Fracking. Retrieved September 03, 2013, from http://www.arte.tv/guide/de/048358-010/x-enius 